Abstracta Iranica Abstracta Iranica

Revue bibliographique pour le domaine irano-aryen

Volume 31 | 2011

Comptes rendus des publications de 2008

\title{
«Une peinture kouchane sur toile ». CRAI, 2006 [2008], p. 955-960.
}

\section{Étienne de La Vaissière}

\section{(2) OpenEdition \\ 1 Journals}

\section{Édition électronique}

URL : http://journals.openedition.org/abstractairanica/39146

DOI : 10.4000/abstractairanica.39146

ISSN : 1961-960X

Éditeur :

CNRS (UMR 7528 Mondes iraniens et indiens), Éditions de l'IFRI

\section{Édition imprimée}

Date de publication : 15 mai 2011

ISSN : 0240-8910

\section{Référence électronique}

Étienne de La Vaissière, « « Une peinture kouchane sur toile ». CRAI, 2006 [2008], p. 955-960. », Abstracta Iranica [En ligne], Volume 31 | 2011, document 28, mis en ligne le 15 février 2012, consulté le 04 octobre 2020. URL : http://journals.openedition.org/abstractairanica/39146 ; DOI : https://doi.org/ 10.4000/abstractairanica.39146

Ce document a été généré automatiquement le 4 octobre 2020.

Tous droits réservés 


\title{
" Une peinture kouchane sur toile ». CRAI, 2006 [2008], p. 955-960.
}

\author{
Étienne de La Vaissière
}

Dans cet article, incomplet en raison de la mort subite de l'A. le 28 juillet 2006, B. Marshak publie une peinture kouchane provenant du sud du Xinjiang et vendue sur le marché de l'art. Seul exemple connu d'une peinture sur toile de cette époque, elle représente une cérémonie d'investiture mettant en scène probablement le roi kouchan Huvishka (153-191) ainsi que des dignitaires religieux (zoroastriens), civils et militaires, devant un temple. Fr. Grenet, dans sa note additionnelle, apporte d'autres parallèles iconographiques confirmant l'attribution et l'interprétation.

\section{INDEX}

Thèmes : 3.1. Est de l'Iran

\section{AUTEURS}

ÉTIENNE DE LA VAISSIÈRE

EPHE - Paris 